\title{
Investigation of Depression Level of Middle School Students' According to Some Variables
}

\author{
Nurullah Emir EKINCI ${ }^{1}$ \\ ${ }^{\prime}$ Dumlupinar University School of Physical Education and Sport, Kutahya/Turkey \\ Email:etinciemir@gmail.com
}

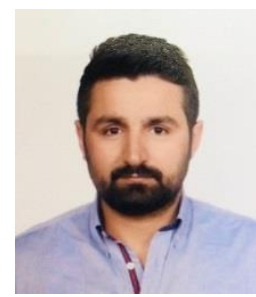

\begin{abstract}
This study investigated the important predictors of depression levels of middle school students' according to their recreational sport participation, gender, age and their socioeconomic status. The data's of the study collected from middle schools in the city center of Kutahya, 342 (113 woman, $198 \mathrm{man}$ ) students randomly recruited and voluntarily participate to the study, age range 11-15. The easy sampling method was preferred in the present study. As a data collection tool "Depression Scale for Kids" was used improved by Kovacs (1985) and adapted to Turkish by Öy (1991). In the evaluation of data first skewness and kurtosis values were evaluated and no skewness or kurtosis issues were found. Than reliability of the scale was assessed via Cronbach's alpha method and Cronbach's alpha calculated as .657. Lastly for definition of the data's MannWhitney U and Kruskal Wallis test used. Data analyses were conducted using SPSS version 21. For Windows. As a result there were not any significant difference between gender, age, sport involvement and depression level of the students $(\mathrm{p}>0$, 05). But, there were a significant difference between socioeconomic status and depression level of the students $(p<0$, 05). The difference was between bad income and very good income.
\end{abstract}

Keywords: Depression, Middle school, Student, Recreation.

Citation | Nurullah Emir EKİNCI (2018). Investigation of Depression Level of Middle School Students' According to Some Variables. Asian Journal of Education and Training, 4(4): 280-283. History:

Received: 12 June 2018

Revised: 9 July 2018

Accepted: 26 July 2018

Published: 20 August 2018

Licensed: This work is licensed under a Creative Commons

Attribution 3.0 License (cc)

Publisher:Asian Online Journal Publishing Group
Funding: This study received no specific financial support.

Competing Interests: The author declares that there are no conflicts of interests regarding the publication of this paper.

Transparency: The authors confirm that the manuscript is an honest, accurate, and transparent account of the study was reported; that no vital features of the study have been omitted; and that any discrepancies from the study as planned have been explained.

Ethical: This study follows all ethical practices during writing.

\section{Contents}

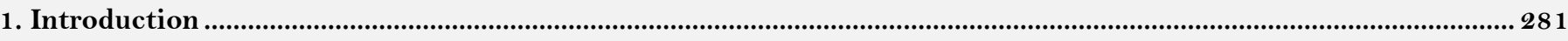

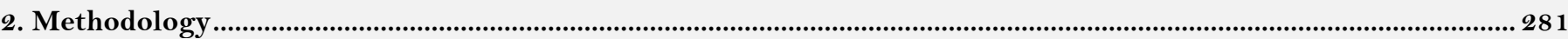

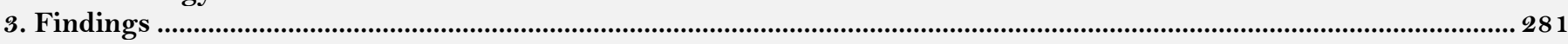

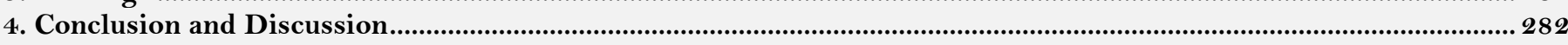

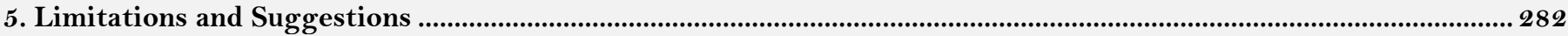

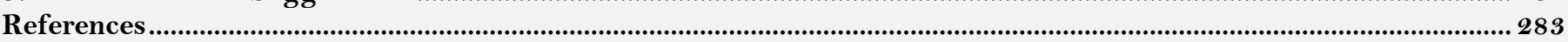




\section{Introduction}

Today's education system is not the only aim at future professions. Schools are obliged not only to provide information but also to socialize the individual. Because there are lots of depressive symptoms and poor coping skill exist for students, who constantly deal with multiple stressors in a complex society (Puskar et al., 2003). Depression is among one of the most disabling disorders and frequently begins early in life (Fergusson and Woodward, 2002). Depression is a syndrome with symptoms, a feeling or a state of depression in the deep gloom of thought, slow down and recession on speech and movements, negative expectations, worthlessness, hopelessness, smallness, weakness, reluctance, pessimism, slowdown on thoughts and feelings with physiological functions, increases the risk of suicide and school refusal (Craft and Perna, 2004; Essau et al., 2013; Ollendick, 2013).

Depression is a common and persistent mental illness in children and has detrimental effects on child development feelings and physical well-being (Brosse et al., 2002; Costello et al., 2011; Sun and Wang, 2015).

It is known that as a part of the social life sport not only upgrades the quality of life but also has a therapeutic effect on depression (Martikainen et al., 1999). Several reviews of the literature have focused on observational and intervention studies which have assessed the relationship between physical activity and depression (Paluska and Schwenk, 2000; Rohan et al., 2004)(O'Neal \& Dunn, 2000). Self-reported level of recreational physical activity correlated with better mental health, including fewer symptoms of both anxiety and depression, after controlling for confounding variables including sex, age, socioeconomic status, and physical illness (Salmon, 2001). Also, its known that sports increase serotonin and endorphins hormone, reduced stress reactivity, and activity related increases in control, mastery, self-efficacy, physical health as well as mental health benefits (Mackenbach et al., 1997; Karakaya et al., 2006).

Depression is a mental disorder affecting performance and some social skills that can lead to serious problems if left untreated (Saxena et al., 2005). That is why; our motivation in this study was to investigate the effect of gender, age, welfare and sport on the depression level of middle school students to see the positive and negative effect of variables on middle school students.

\section{Methodology}

\subsection{Study Design}

In the study, a cross-sectional method used as study design, and according to Gratton and Jones (2010) this method is perhaps the most commonly used method in social and sport based studies. According to this method, the data obtained from a sampling group relationship is identified and generalized back to the population.

\subsection{Sampling Group}

A total of 414 randomly chosen primary school students from several schools of Kutahya city center - a city in the west part of Turkey with the population of 325.000- voluntarily participated in the study. But, after outliers were analyzed answers of 10 students eliminated. So finally the sampling group has consisted of 404 primary students $[(\mathrm{N}=173)$ female, $(\mathrm{N}=231)$ male $]$.

\subsection{Data Collection Tool}

Different methods such as clinical interviews, structured interviews, and self-report questionnaires have been developed to measure depression symptoms. The Children's Depression Inventory (Kovacs, 1985) is the most established self-report measure of depressive symptoms in children. It is intended to measure depressive symptoms in children 7-17 years old with basic reading and comprehension skills. In the present study, a Turkish version of Kovacs (1985) the Children's Depression Inventory (CDI) was used. The Turkish adaptation of the scale was done by Öy (1991). The CDI is a 3-item Likert type, single-dimension scale made up of 27 questions. Possible total score range from $\mathrm{O}$ to 54 . Higher scores indicating higher levels of depressive symptoms. The Cronbach's alpha coefficient was .80 . For each item on the CDI, children are asked to endorse one of three statements that best describe the way they have been feeling during the past two weeks (e.g., "I am sad once in a while," "I am sad many times," or "I am sad all the time"). Responses are scored quantitatively on a scale of o (the symptom is not present), 1 (the symptom is present and mild), and 2 (the symptom is present and marked).

\subsection{Data Analyses}

SPSS 22 software program (SPSS Inc., Chicago IL, USA) was used for statistical analysis. In the analysis of the data; mean value is given as the descriptive statistic. Kolmogorov-Smirnov test was used for the normality of data. Moreover, Mann Whitney U test and Kruskal Wallis $\mathrm{H}$ test applied for comparison of categorical variables and Dunn's post hoc test was used for multiple comparison tests after Kruskal Wallis H test. The level of significance was set at $5 \%$. Cronbach's alpha value of the scale was calculated as .753 in the present study.

\section{Findings}

Table-1. Mann Whitney U Test Results According to Recreational Sports Participation and Gender Variable.

\begin{tabular}{l|l|l|l|l}
\hline Recreational Sports & N & Mean & U & p \\
\hline Yes & 239 & 152.43 & 7751.5 & 0.199 \\
\hline No & 72 & 167.84 & & \\
\hline Gender & N & Mean & U & p \\
\cline { 1 - 2 } Woman & 113 & 145.85 & 10040.5 & 0.130 \\
\hline Man & 198 & 161.79 & & \\
\hline
\end{tabular}


According to Table 1 analysis results shows that there is no any significant differences between depression and recreational sports participation $(\mathrm{U}=7751.5 ; \mathrm{p}=0.199 ; \mathrm{p}>0.05)$. Also between depression and gender $(\mathrm{U}=100400.5$; $\mathrm{p}=0.130 ; \mathrm{p}>0.05)$.

Table-2. Kruskal Wallis Test Result According to Age Variable

\begin{tabular}{l|l|l|l|l}
\hline Age & $\mathbf{N}$ & Mean & $\mathbf{~}$ & $\mathbf{p}$ \\
\hline $9-11$ & 105 & 152.33 & 1.01 & 0.603 \\
\hline $12-14$ & 114 & 162.69 & & \\
\cline { 1 - 2 } $14+$ & 92 & 151.90 & & \\
\hline$p>0,05$ & & & \\
\hline
\end{tabular}

According to Table 2 analysis results shows that there is no any significant differences between depression and age $\left(\mathrm{x}^{2}=1.01 ; \mathrm{p}=0.603 ; \mathrm{p}>0.05\right)$.

Table-3. Kruskal Wallis test Result According to Their Socioeconomic Status.

\begin{tabular}{|c|c|c|c|c|}
\hline Economic Status & $\mathbf{N}$ & Mean & $x^{2}$ & p \\
\hline Bad & 20 & 215.40 & \multirow[t]{4}{*}{15.476} & \multirow[t]{4}{*}{$0.001^{*}$} \\
\hline Normal & 104 & 157.99 & & \\
\hline Good & 140 & 157.23 & & \\
\hline Very good & 47 & 122.65 & & \\
\hline Difference Between Groups & $\mathbf{N}$ & Mean & $\mathbf{U}$ & $\mathbf{P}$ \\
\hline Bad & 20 & 47.63 & \multirow[t]{2}{*}{197.5} & \multirow[t]{2}{*}{$0.001^{*}$} \\
\hline Very good & 47 & 28.20 & & \\
\hline
\end{tabular}

According to Table 3 analysis results shows students' socioeconomic status according to data's 20 students have "Bad," 104 students have "Normal," 140 students have "Good," 47 students have "Very good" income level. Analyses of the data show there was a significant difference between depression and income level of students $\left(\mathrm{x}^{2}=15.476 ; \mathrm{p}=0.001 ; \mathrm{p}<0.05\right)$. To determine the binary combination of groups Mann-Whitney $\mathrm{U}$ test is done. Test results showed that the significant difference was between students who have "bad" income level and the students who have "very good" income level $(\mathrm{U}=197.5$; $\mathrm{p}=$, 000; $\mathrm{p}<0.05)$.

\section{Conclusion and Discussion}

According to the findings of the study, there were no significant differences in depression scores of students' recreational sports activities participation. However, depression scores of the students who engaged in recreational sports activities have been identified much less than students who not participated. In the literature, there are some studies which support this result. According to Strawbridge et al. (2002) individuals with low activity levels were at much higher risk for depression compared to a high activity reference group. Kritz et al. (2001) found that more intensive and frequent activity associated with lower scores on depression. Also, individuals who engage in more physical activity are less likely to be concurrently depressed (Tsuang and Faraone, 1990; Mackenbach et al., 1997; O'Neal et al., 2000).

It has observed that there were no significant differences in depression level between students according to the gender variable. The reason can be taught that under the terms of their ages, students are similarly emotional, self-conscious and have stress at the same level (Erözkan, 2009). In contrast to this result, in general, according to gender variable, significant differences have been observed in other studies (Brosse et al., 2002; Arslan et al., 2011). For instance, in the study of Eskin et al. (2008). About the factors related to depression in high school students, they found that 141 students (17.5\%) scored on and above the cut-off point on the Children Depression Inventory (CDI) were the girl. Also, it has determined that there were no significant differences according to gender variable in Ören and Gençdoğan (2007) study on students who attend high school. According to Essau et al. (2013) studies that used self-report questionnaires such as the Centre for Epidemiological Studies Depression Scale for Children (CES-DC) have similarly shown girls to report significantly higher levels of depressive symptoms than boys.

According to analyses results, there were no significant differences in depression scores of the students who are in different age ranges. Also Karakaya et al. (2006). Did not find any significant difference on professional swimmer children. According to the above result, we may say a small age difference between students gives the same effect. The study of Bettge et al. (2008) support this theory. According to Bettge depressive symptoms were significantly higher among adolescents (12-18 years) than children (6-11 years). Also in the literatüre, some studies showed that there is a significant relationship between the prevalence of depression and age (Kashani et al., 1987).

Analyses result showed that there was a significant difference between the socioeconomic status of the students. Results showed that the difference was between the students who have bad income and the students who had very good income level. According to Lawlor and Hopker (2001) and Lopez et al. (2006) low socioeconomic status is related to higher rates of morbidity and mortality and has been shown to be a significant predictor of poor functioning. Also, the highest potential for increased health and reduced mortality is in taking on physical activity (Lotan et al., 2005).

\section{Limitations and Suggestions}

It can be shown as an obstacle for a more comprehensive study that there are not enough studies which relate sports and depression and the researchers exist are mostly studied for adults. Therefore it is thought that studies in this area should be increased. Also, further studies may focus on larger example groups. 


\section{References}

Arslan, C., M. Güllü and V. Tutal, 2011. Analyzing the depression states of elementary school students who do sports or not according to some variables. Nigde University Journal of Physical Education and Sport Sciences, 5(2): 120-132. View at Google Scholar

Bettge, S., N. Wille, C. Barkmann, M. Schulte-Markwort, U. Ravens-Sieberer and B.S. Group, 2008. Depressive symptoms of children and adolescents in a German representative sample: Results of the BELLA study. European Child \& Adolescent Psychiatry, 17(S1): 7181. View at Google Scholar $\mid$ View at Publisher

Brosse, L., S. Sheets, H. Lett and A. Blumenthal, 2002. Exercise and the treatment of clinical depression in adults. Sports Medicine, 32(12): 741-760. View at Google Scholar | View at Publisher

Costello, E.J., W. Copeland and A. Angold, 2011. Trends in psychopathology across the adolescent years: What changes when children become adolescents, and when adolescents become adults? Journal of Child Psychology and Psychiatry, 52(10): 1015-1025. View at Google Scholar | View at Publisher

Craft, L.L. and F.M. Perna, 2004. The benefits of exercise for the clinically depressed. Primary Care Companion to the Journal of Clinical Psychiatry, 6(3): 104-111. View at Google Scholar | View at Publisher

Erözkan, A., 2009. The predictors of depression in eighth grade primary school students. Elementary Education Online, 8(2): 334-345. View at Google Scholar

Eskin, M., K. Ertekin, H. Harlak and Ç. Dereboy, 2008. The prevalence of depression in high school student ergens and related factors. Turkish Journal of Psychiatry, 19(4): 382-389.

Essau, C.A., B. Olaya, G. Pasha, C. Gilvarry and D. Bray, 2013. Depressive symptoms among children and adolescents in iran: A confirmatory factor analytic study of the centre for epidemiological studies depression scale for children. Child Psychiatry \& Human Development, 44(1): 123-136. View at Google Scholar $\mid$ View at Publisher

Fergusson, D.M. and L.J. Woodward, 2002. Mental health, educational, and social role outcomes of ado- lescents with depression. Archives of General Psychiatry, 59(3): 225-231. View at Google Scholar | View at Publisher

Gratton, C. and I. Jones, 2010. Research methods for sports studies. 2nd Edn., London: Routledge.

Karakaya, I., A. Coşkun and B. Ağaoğlu, 2006. Evaluation of depression, self-esteem and anxiety levels of the players. Anadolu Psikiyatri Magazine, 7(3): 162-166.

Kashani, J.H., G.A. Carlson, N.C. Beck, E.W. Hoeper, C.M. Corcoran, J.A. McAllister and J.C. Reid, 1987. Depression, depressive symptoms, and depressed mood among a community sample of adolescents. American Journal of Psychiatry, 144(7): 93 1-934. View at Google Scholar $\mid$ View at Publisher

Kovacs, M., 1985. The children's depression inventory (CDI). Psychopharmacol Bulletin, 21(4): 995-998. View at Google Scholar

Kritz, D., E. Barrett and C. Corbeau, 2001. Cross-sectional and prospective study of exercise and depressed mood in the elderly: The Rancho Bernardo study. American Journal of Epidemiology, 153(6): 596-603. View at Google Scholar $\mid$ View at Publisher

Lawlor, D.A. and S.W. Hopker, 2001. The effectiveness of exercise as an intervention in the management of depression: Systematic review and meta-regression analysis of randomised controlled trials. British Medical Journal, 322(7289): 763-763. View at Google Scholar $\mid$ View at Publisher

Lopez, A.D., C.D. Mathers, M. Ezzati, D.T. Jamison and C.J. Murray, 2006. Global burden of disease and risk factors. Washington, DC: World Bank and Oxford University Press.

Lotan, M., J. Merrick and E. Carmeli, 2005. A review of physical activity and well-being. International Journal of Adolescent Medicine and Health, 17(1): 23-32. View at Google Scholar | View at Publisher

Mackenbach, J.P., A.E. Kunst, A.E. Cavelaars, F. Groenhof and J.J. Geurts, 1997. EU working group on socioeconomic inequalities in health. Socioeconomic inequalities in morbidity and mortality in Western Europe. Lancet, 349(9066): 1655-1659. View at Google Scholar

Martikainen, P., S. Stansfeld, H. Hemingway and M. Marmot, 1999. Determinants of socioeconomic differences in change in physical and mental functioning. Social Science \& Medicine, 49(4): 499-507. View at Google Scholar | View at Publisher

O'Neal, H.A., A.L. Dunn and E.W. Martinsen, 2000. Depression and exercise. International Journal of Sport Psychology, $31(2)$ : 1 10-135. View at Google Scholar

Ollendick, T.H., 2013. Handbook of child psychopathology. Springer Science \& Business Media.

Ören, N. and B. Gençdoğan, 2007. Examination of depression levels of high school students according to some variables. Kastamonu Education Journal, 15(1): 85-92.

Öy, B., 1991. Depression scale for children: Validity reliability study. Journal of Turkish Psychiatry, 2(2): 132-136. View at Google Scholar

Paluska, S.A. and T.L. Schwenk, 2000. Physical activity and mental health. Sports Medicine, 29(3): 167-180. View at Google Scholar

Puskar, K., S. Sereika and K. Tusaie-Mumford, 2003. Effect of the teaching kids to cope (TKCC) program on outcomes of depression and coping among rural adolescents. Journal of Child and Adolescent Psychiatric Nursing, 16(2): 71-80. View at Google Scholar $\mid$ View at

Publisher
Rohan, K.J., K.T. Lindsey, K.A. Roecklein and T.J. Lacy, 2004. Cognitive-behavioral therapy, light therapy, and their combination in treating seasonal affective disorder. Journal of Affective Disorders, 80(2-3): 273-283. View at Google Scholar $\mid$ View at Publisher

Salmon, P., 2001. Effects of physical exercise on anxiety, depression, and sensitivity to stress: A unifying theory. Clinical Psychology Review, 21(1): 33-61. View at Google Scholar | View at Publisher

Saxena, S., M. Van Ommeren, K.C. Tang and T.P. Armstrong, 2005. Mental health benefits of physical activity. Journal of Mental Health, 14(5): 445-451. View at Google Scholar | View at Publisher

Strawbridge, W.J., S. Deleger, R.E. Roberts and G.A. Kaplan, 2002. Physical activity reduces the risk of subsequent depression for older adults. American Journal of Epidemiology, 156(4): 328-334. View at Google Scholar | View at Publisher

Sun, S. and S. Wang, 2015. The children's depression inventory in worldwide child development research: A reliability generalization study. Journal of Child and Family Studies, 24(8): 2352-2363. View at Google Scholar | View at Publisher

Tsuang, M.T. and S.V. Faraone, 1990. The genetics of mood disorders. Johns Hopkins University Press. 